\title{
PERENCANAAN INVERTER PWM SATU FASA UNTUK PENGATURAN TEGANGAN OUTPUT PEMBANGKIT TENAGA ANGIN
}

\author{
Oleh \\ Herisajani, Nasrul Harun, Dasrul Yunus \\ Staf Pengajar Teknik Elektro Politeknik Negeri Padang
}

\begin{abstract}
Inverter as power circuit is used to change DC to AC voltage. In general, DC which can be changed by inverter is DC voltage with constant value, for example battery or accu. Inverter is design to changed non constant DC voltage which produced by wind power generator become constant ac voltage. In changing process from non constant DC voltage to constant $A C$ voltage is controlled by microcontroller to simplify the design of inverter.
\end{abstract}

Keyword: inverter, microcontroller

\section{PENDAHULUAN}

Kebutuhan sumber daya energi alternatif sudah merupakan isu umum sebagai upaya untuk mengantisipasi peningkatan pemakaian energi dan menipisnya sumber energi konvensional. Beberapa sumber energi alternatif baru terus dikembangkan dan salah satunya adalah sumber energi listrik dengan menggunakan potensi tenaga angin. Namun demikian energi listrik yang dihasilkan dari potensi tenaga angin ini masih dalam kategori skala kecil $\leq 1 \mathrm{~kW}$. Umumnya energi listrik dari tenaga angin ini dijumpai pada tempat-tempat yang terpencil yang belum terjangkau oleh aliran listrik PLN. Direncanakan membuat sebuah prototype berupa alat dengan inverter satu fasa sebagai bagian dari rangkaian sistem pengatur tegangan output pembangkit tenaga angin yang berubah-ubah.Tegangan output generator pembangkit tenaga angin diatur sedemikian rupa oleh mikrokontroler sehingga menjadi tegangan yang konstan. Dari tegangan yang konstan ini kemudian dijadikan tegangan ac dengan menggunakan rangkaian inverter satu fasa dan diharapkan tegangan ac yang didapatkan sebesar 220 Volt / $50 \mathrm{~Hz}$.

\section{DASAR TEORI}

\section{Inverter satu fasa}

Rangkaian pengubah DC to DC disebut juga dengan inverter. Fungsinya adalah untuk mengubah tegangan input DC menjadi tegangan output AC yang simetris dimana amplitudo dan frekwensinya bisa diatur. Tegangan output dapat diperoleh dengan mengubah tegangan input DC atau dengan merubah metode switching atau pensaklaran pada inverter. Untuk daya rendah atau daya medium, tegangan output bentuk persegi atau quasi persegi sudah cukup, sedangkan untuk daya tinggi maka tegangan output bentuk sinus dengan kandungan harmonisanya yang rendah harus benar-benar diperhitungkan. Inverter secara luas digunakan dalam industri seperti untuk penggerak motor dengan kecepatan variable, HVDC, UPS,dll. Sumber tegangan input pada inverter bisa diperoleh dari baterai, 
fuelcell, solar cell, dan sumber dc lainnya.

\section{Boost converter}

Boost converter merupakan jenis konverter $\mathrm{dc}$ to dc untuk menaikkan tegangan input yang tetap ke level tegangan yang lebih tinggi sesuai dengan keinginan. Proses transfer energi dari sumber ke beban hanya terjadi ketika siklus off dari satu periode switching

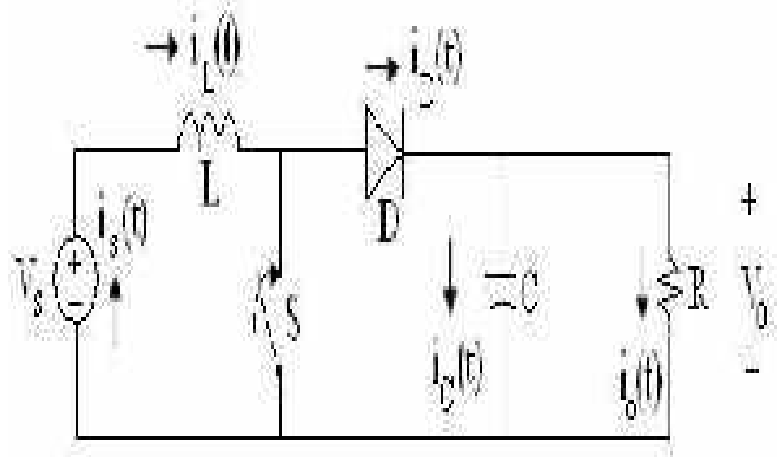

Gambar 1. Rangkaian dasar boost converter

Saklar S merupakan komponen saklar elektronik yang dioperasikan dengan mode saturasi (on) dan mode cutoff (off ). Saklar S dapat berupa transistor BJT, MOSFET, IGBT atau komponen solid state lainnya.

Hubungan antara tegangan input dan output pada boost converter ditentukan dengan persamaan berikut:

$$
V_{0}=\frac{V_{S}}{1-D}
$$

Dimana :

$$
\begin{aligned}
& V_{O}=\text { Tegangan output (Volt) } \\
& V_{S}=\text { Tegangan sumber atau } \\
& \text { input (Volt) } \\
& \mathrm{D}=\quad \text { Duty cycle atau lamanya } \\
& \text { waktu saklar S tertutup dalam satu } \\
& \text { periode }
\end{aligned}
$$

Arti persamaan (1) diatas yaitu penguatan tegangan input hanya bergantung pada lamanya saklar $\mathrm{S}$ terhubung dalam satu periode switching. Lamanya waktu saklar terhubung juga disebut sebagai duty cycle dan karena nilai duty cycle selalu lebih kecil daripada 1 maka Vo dipastikan selalu lebih besar dari Vs [5] .

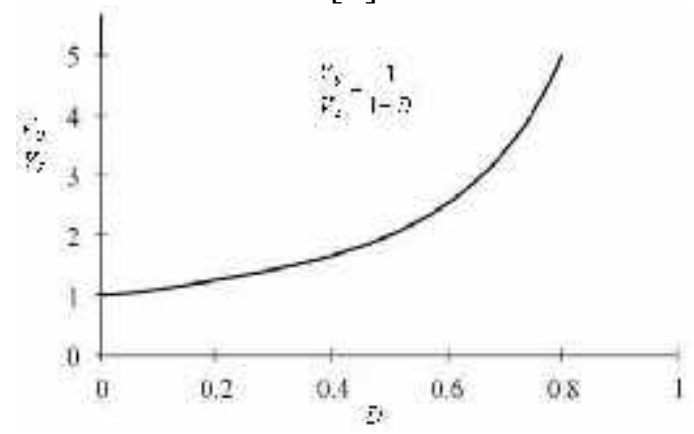

Gambar 2. Hubungan duty cycle dan penguatan input boost converter

\section{Komponen Daya}

Komponen daya terbuat dari bahan semikonduktor yang berfungsi sebagai saklar elektronik. Komponen daya yang sering digunakan adalah: tiristor, transistor, MOSFET dan GTO. Masing-masing komponen memiliki ciri yang khas. Pada transistor pengendalian komutasi dengan arus base (ib), sedangkan pada MOSFET dilakukan dengan tegangan $\mathrm{V}_{\mathrm{GS}}$. Bila kecepatan tinggi diperlukan, maka MOSFET merupakan komponen daya terbaik. Tiristor dan transistor dapat digunakan pada frekuensi $400 \mathrm{~Hz}-2 \mathrm{KHz}$, sedangkan MOSFET dapat digunakan pada frekuensi antara $20 \mathrm{KHz}-200 \mathrm{KHz}$. Contoh daerah penggunaan komponen daya pada sebuah inverter diperlihatkan pada gambar 3 .

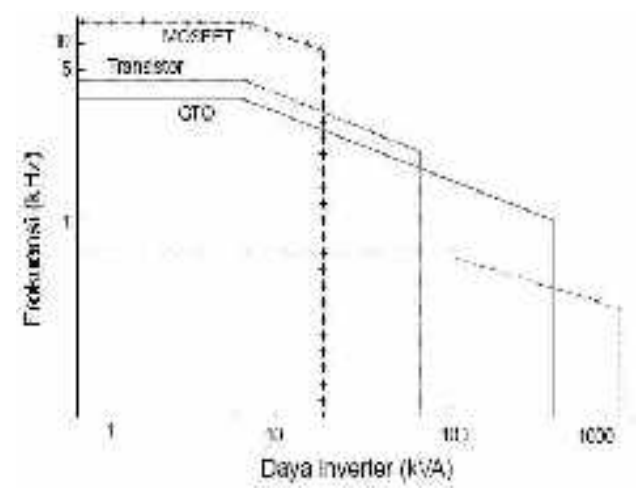

Gambar 3. Daerah penggunaan komponen daya 


\section{PERANCANGAN SISTEM}

Diagram blok sistem keseluruhan dari perancangan adalah sebagai berikut:

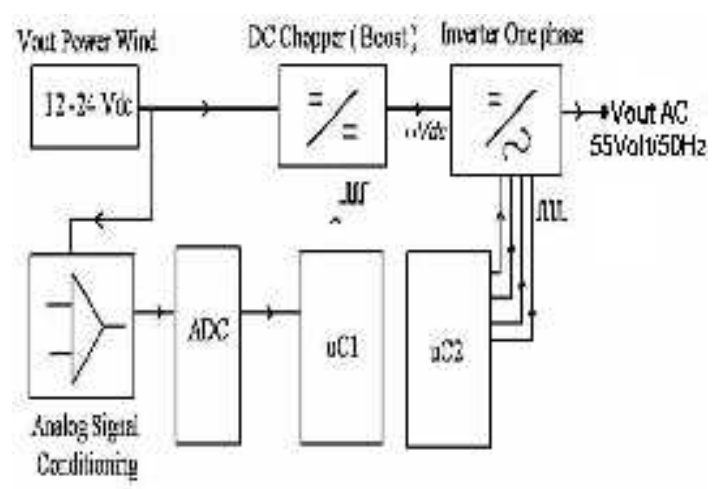

Gambar 4. Diagram Blok Sistem keseluruhan

\section{Perancangan Perangkat Keras}

Perancangan perangkat keras meliputi:

- Rangkaian boost converter,

- Rangkaian daya inverter satu fasa,

- Rangkaian picu gate mosfet inverter satu fasa

- Rangkaian picu gate mosfet boost converter

- Rangkaian sistem minimum ATMEGA8535

- Rangkaian sistem minimum AT89C51

- Rangkaian pengkondisi sinyal

- Rangkaian ADC 0804 dan

\section{Rangkaian Boost converter}

Rangkaian ini digunakan untuk menaikkan tegangan dc dari generator dari 12 hingga 24 volt atau sebaliknya supaya menjadi 55 volt konstan. Switch pada boost converter akan di triger dengan duty cycle yang berbeda-beda disesuaikan dengan tegangan yang keluar dari generator.
Tabel 1. Hubungan Vs, D dan Vout perancangan boost converter

\begin{tabular}{|l|l|l|l|l|}
\hline $\begin{array}{l}\text { Vs } \\
\text { (Volt) }\end{array}$ & $\begin{array}{l}\text { Duty } \\
\text { Cycle D }\end{array}$ & $\begin{array}{l}\text { Ton } \\
\text { (uS) }\end{array}$ & $\begin{array}{l}\text { Toff } \\
\text { (uS) }\end{array}$ & $\begin{array}{l}\text { Vout } \\
\text { (Volt) }\end{array}$ \\
\hline 12 & 0,78 & 19,5 & 5,5 & 55 \\
\hline 13 & 0,76 & 19 & 6 & 55 \\
\hline 14 & 0,74 & 18,5 & 6,5 & 55 \\
\hline 15 & 0,72 & 18 & 7 & 55 \\
\hline 16 & 0,7 & 17,5 & 7,5 & 55 \\
\hline 17 & 0,69 & 17,25 & 7,75 & 55 \\
\hline 18 & 0,67 & 16,75 & 8,25 & 55 \\
\hline 19 & 0,65 & 16,25 & 8,75 & 55 \\
\hline 20 & 0,63 & 15,75 & 9,25 & 55 \\
\hline 21 & 0,61 & 15,25 & 9,75 & 55 \\
\hline 22 & 0,6 & 15 & 10 & 55 \\
\hline 23 & 0,58 & 14,5 & 10,5 & 55 \\
\hline 24 & 0,56 & 14 & 11 & 55 \\
\hline
\end{tabular}

\section{Rangkaian daya inverter satu fasa}

Rangkaian dibuat dalam bentuk konfigurasi jembatan penuh satu fasa yang terdiri dari 4 buah mosfet sebagai saklar. Rangkaian ini digunakan untuk mengubah tegangan dc yang konstan sebesar 55 volt dari boost converter menjadi tegangan ac 55 volt $/ 50 \mathrm{~Hz}$.

\section{Rangkaian picu gate mosfet inverter} Rangkaian ini digunakan sebagai pemicu gate mosfet dari rangkaian daya inverter satu fasa. Terdiri dari rangkaian isolasi dan totem pole.

\section{Rangkaian picu gate mosfet boost converter}

Rangkaian ini digunakan sebagai pemicu gate mosfet dari rangkaian boost converter. Terdiri dari rangkaian inverting dan totem pole.

\section{Rangkaian Sistem minimum ATMEGA8535}

Rangkaian ini terdiri sebuah mikrokontroler ATMEGA8535 dan sebuah rangkaian picu gate mosfet boost converter. Proses pengontrolan tegangan dc yang bervariasi dari 12 hingga 24 volt 
menjadi 55 volt dc yang konstan pada output boost converter, sepenuhnya dilakukan oleh mikrokontroler ATMEGA8535.

Pengontrolan tegangan yang dilakukan oleh mikrokontroler ATMEGA8535 supaya boost converter menghasilkan tegangan vout 55 volt konstan, dilakukan dengan pembacaan tegangan dari generator ( tegangan input boost converter) setiap saat.

Berikut adalah prosedurnya.

\section{-If $V s=12$ volt Then $D=0,78$}

maksudnya jika tegangan input boost converter atau tegangan generator dibaca 12 volt, maka saklar boost converter di trigger dengan duty cycle sebesar 0,78 , sehingga vout sebesar 55 volt

\section{-If $V s=13$ volt Then $D=0,76$}

maksudnya jika tegangan input boost converter yang dibaca 13 volt, maka saklar boost converter di triger dengan duty cycle sebesar 0,76 sehingga vout sebesar 55 volt.

Begitu seterusnya hingga $\mathrm{Vs}=24$ volt.

\section{Rangkaian Sistem minimum AT89C51}

Rangkaian ini terdiri dari sebuah mikrokontroler AT89C51. 4 pin dari mikro ini dihubungkan ke rangkaian picu gate mosfet inverter . fungsi utamanya adalah untuk mengoperasikan atau mentriger rangkaian daya inverter satu fasa agar inverter dapat mengubah tegangan 55 volt dc dari rangkaian boost converter menjadi tegangan ac 55 volt/ $50 \mathrm{~Hz}$.

\section{Rangkaian Pengkondisi sinyal}

Rangkaian pengkondisi sinyal digunakan untuk menyesuaikan suatu
If $\mathrm{Vs}_{\mathrm{s}}=12$ volt ThenD $=0,78$

If $\mathrm{Vs}=13$ volt Then $\mathrm{D}=0,76$

If $\mathrm{Vs}=14$ volt Then $\mathrm{D}=0,74$

If $\mathrm{Vs}=15$ volt Then $\mathrm{D}=0,72$

If $\mathrm{Vs}=16$ volt Then $\mathrm{D}=0,70$

If $\mathrm{Vs}=17$ voltThenD $=0,69$

If $\mathrm{Vs}=18$ volt Then $\mathrm{D}=0,67$

If $\mathrm{Vs}=19$ volt Then $\mathrm{D}=0$,

If $\mathrm{Vs}=20$ volt Then $\mathrm{D}=0,63$

If $\mathrm{Vs}_{\mathrm{s}}=21$ volt Then $\mathrm{D}=0,61$

If $\mathrm{Vs}=22$ volt Then $\mathrm{D}=0,60$

If $\mathrm{Vs}_{\mathrm{s}}=23$ volt Then $\mathrm{D}=0,58$

If $\mathrm{Vs}=24 \mathrm{vol}$ Then $\mathrm{D}=0,56$

sinyal masukan supaya mendapatkan sinyal keluaran sesuai dengan yang diinginkan. Pada perancangan ini rangkaian pengkondisi sinyal digunakan untuk mengubah tegangan 12 hingga 24 volt dari generator ke tegangan 0-5 volt supaya dapat dibaca oleh mikrokontroler ATMEGA setelah sebelumnya tegangan 0-5 tersebut dikonversikan terlebih dahulu lewat ADC. Rangkaian pengkondisi sinyal ini terdiri dari rangkaian differensial amplifier (sebagai pengubah 12 - 24 ke 0-5 volt ) dan rangkaian buffer ( untuk menjaga agar tidak terjadi drop tegangan yang masuk pada ADC ).

\section{Rangkaian ADC 0804}

Rangkaian ini digunakan untuk mangkonversi tegangan analog 0-5 volt ( dalam hal ini mewakili 12-24 dari generator ) ke data digital agar dapat dibaca oleh mikrokontroler ATMEGA8535.

HASIL PENGUJIAN DAN ANALISA

1. Hasil Pengujian rangkaian pengkondisi sinyal setelah simulasi dan setelah direalisasikan 
Tabel 2. Tegangan output rangkaian pengkondisi sinyal hasil

\begin{tabular}{|c|c|c|}
\hline $\begin{array}{c}\text { Teg.input (Teg. Generator) } \\
\text { (Volt) }\end{array}$ & $\begin{array}{c}\text { Vout pengkondisi sinyal } \\
\text { simulasi (Volt) }\end{array}$ & $\begin{array}{c}\text { Vout pengkondisi sinyal } \\
\text { realisasi (Volt) }\end{array}$ \\
\hline 12 & 0,001 & 0,006 \\
\hline 13 & 0,43 & 0,412 \\
\hline 14 & 0,84 & 0,833 \\
\hline 15 & 1,26 & 1,251 \\
\hline 16 & 1,68 & 1,67 \\
\hline 17 & 2,09 & 2,086 \\
\hline 18 & 2,51 & 2,495 \\
\hline 19 & 2,93 & 2,919 \\
\hline 20 & 3,34 & 3,341 \\
\hline 21 & 3,76 & 3,758 \\
\hline 22 & 4,18 & 4,16 \\
\hline 23 & 4,59 & 4,59 \\
\hline 24 & 5,01 & 5,02 \\
\hline
\end{tabular}

Dari tabel 2 terlihat bahwa tegangan keluaran

atau Vout dari rangkaian pengkondisi sinyal baik simulasi maupun setelah direalisasikan dengan nilai Vs yang sama diperoleh nilai Vout yang sangat mirip, dengan demikian rangkaian yang dibangun sudah sesuai dengan harapan.

\section{Hasil Pengujian Rangkaian ADC 0804}

Pengujian ADC dilakukan dengan cara

menghubungkan output rangkaian pengkondisi sinyal kebagian input rangkaian ADC . Jika melihat tabel 3 terlihat bahwa data output ADC yang diperoleh setelah realisasi rata-rata mengalami tidak sama dengan data output ADC yang seharusnya (teori), hal ini dikarenakan karakteristik dari ADC itu sendiri.

Tabel 3. Hasil pengujian ADC 0804

\begin{tabular}{|l|c|c|c|c|}
\hline Input ADC & \multicolumn{2}{|c|}{ Output ADC(Hex) } & \multicolumn{2}{c|}{ Out ADC (desimal) } \\
\hline (Volt) & teori & Realisasi & teori & realisasi \\
\hline 0,05 & 0 & 0 & 1 & 1 \\
\hline 0,412 & 15 & 15 & 21 & 21 \\
\hline 0,833 & $2 \mathrm{~A}$ & $2 \mathrm{~A}$ & 42 & 42 \\
\hline 1,251 & $3 \mathrm{~F}$ & $3 \mathrm{~F}$ & 63 & 63 \\
\hline 1,67 & 55 & 54 & 85 & 84 \\
\hline 2,086 & $6 \mathrm{~A}$ & 69 & 106 & 105 \\
\hline 2,495 & $7 \mathrm{~F}$ & $7 \mathrm{D}$ & 127 & 125 \\
\hline 2,919 & 94 & 93 & 148 & 147 \\
\hline 3,341 & AA & A9 & 170 & 169 \\
\hline 3,758 & BF & BD & 191 & 189 \\
\hline 4,16 & D4 & D2 & 212 & 210 \\
\hline 4,59 & E9 & E7 & 234 & 231 \\
\hline 5,001 & FF & FF & 255 & 255 \\
\hline
\end{tabular}




\section{Hasil pengujian rangkaian driver boost converter.}

Pulsa input rangkaian driver boost converter dibangkitkan oleh mikrokontroler

ATMEGA8535 sedangkan pulsa output yang digunakan untuk mentriger saklar (gate mosfet) rangkaian boost converter yaitu pulsa dari bagian totem polenya. Hasil pengujian rangkaian driver boost converter dilihat pada gambar 5 berikut:

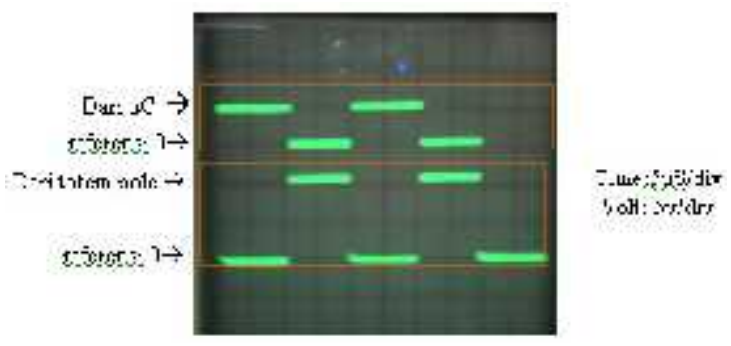

Gambar 5. Pulsa triger dari driver boost converter

Terlihat bahwa pulsa triger yang dihasilkan oleh rangkaian driver boost converter sudah sesuai dengan perancangan, dimana pulsa yang diharapkan Pulsa dengan tegangan 0 $12 \mathrm{v}$.

\section{Hasil pengujian rangkaian driver inverter}

Sama seperti pada pengujian rangkaian driver boost converter hanya saja disini pulsa input rangkaian driver inverter dibangkitkan oleh mikrokontroler AT89C51 dan pulsa output dari bagian totem pole rangkaian digunakan untuk mentriger saklar (gate mosfet) inverter full bridge satu fasa. Hasil pengujian dilakukan dengan mengukur pulsa dari totem pole rangkaian seperti yang ditunjukkan oleh Gambar 6.

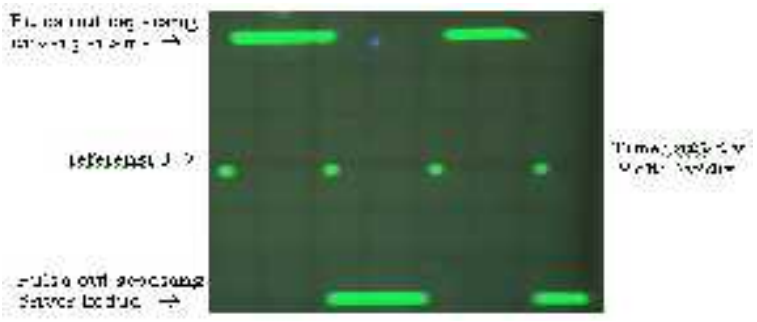

Gambar 6. PulsaPulsa triger dari driver inverter

\section{Hasil pengujian rangkaian boost converter dengan simulasi}

Pengujian rangkaian boost converter terdiri dari tahap, pertama dengan simulasi, dan kedua pengujian setelah realisasi alat. Untuk simulasi, rangkaian boost converter disimulasikan dengan software proteus 6.02. Hasil pengujian dengan simulasi dapat dilihat pada tabel 4 .

Table 4. Pengujian rangkaian boost converter dengan simulasi

\begin{tabular}{|l|l|l|}
\hline Vs (Volt) & $\mathrm{D}(\%)$ & Vout (Volt) \\
\hline 12 & 78,1818 & 55 \\
\hline 13 & 76,3636 & 54,9999 \\
\hline 14 & 74,5454 & 54,9999 \\
\hline 15 & 72,7272 & 54,9999 \\
\hline 16 & 70,909 & 54,9998 \\
\hline 17 & 69,0909 & 55 \\
\hline 18 & 67,2727 & 55 \\
\hline 19 & 65,4545 & 54,9999 \\
\hline 20 & 63,6363 & 54,9999 \\
\hline 21 & 61,8181 & 54,9999 \\
\hline 22 & 60 & 55 \\
\hline 23 & 58,1818 & 55 \\
\hline 24 & 56,3636 & 55,1 \\
\hline
\end{tabular}

Dari tabel 4. Tegangan input boost converter yang bervariasi antara 12 hingga 24 volt dapat dinaikkan sampai 55 volt tergantung dari nilai duty cycle yang diberikan pada saklar boost converter. 


\section{Hasil pengujian realisasi boost converter}

Disini pengujian dan pengukuran boost converter dilakukan saat seluruh bagian rangkaian dari sistem sudah terhubung. Metoda pengujian rangkaian boost converter yang telah direlisasikan dijelaskan sebagai berikut:

1) Tegangan pada Power supply dc variable diatur besarnya dan diset pada posisi awal 12 volt

2) Mengukur pulsa triger dari rangkaian pemicu gate mosfet boost converter . Dengan menggunakan fluke meter besar duty cycle pulsa juga dapat diketahui.

3) Mengukur besar tegangan output boost converter dalam hal ini tegangan output yang terukur

\section{Hasil pengujian realisasi boost converter saat tegangan inputnya $=12$ volt}

Hasil pengujian rangkaian realisasi boost converter saat tegangan input boost converter atau tegangan dari Power supply pada posisi 12 volt, diukur dengan menggunakan Fluke 43B seperti ditunjukkan pada Gambar 7 dan 8 seharusnya sesuai dengan perencanaan atau simulasi sebesar 55 Volt.

4) Tegangan dari Power supply dc adjustable dinaikkan satu tingkat dari posisi awal

5) Mengukur kembali pulsa triger dan besar duty cycle dari pemicu gate mosfet boost converter seperti langkah (2).

6) Kembali ke langkah (3)

7) Kembali ke langkah (6) hingga tegangan dari Power supply $\mathrm{dc}$ variable yang di atur hingga pada batas 24 volt.

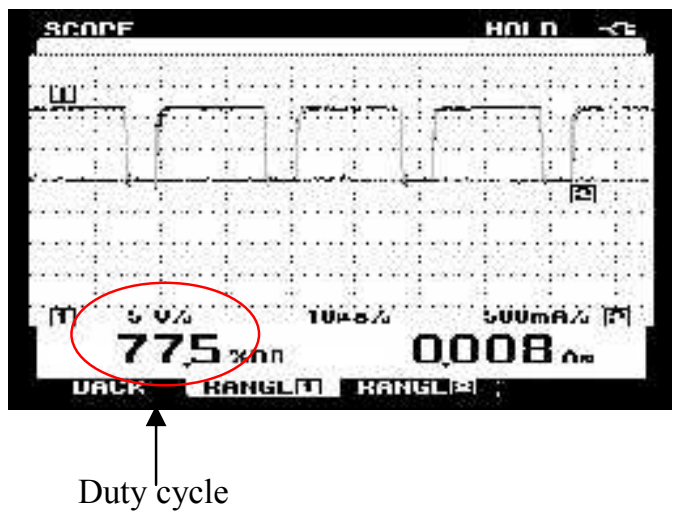

Gambar 7. Bentuk pulsa dan nilai duty cycle boost converter saat tegangan input $=12$ Volt

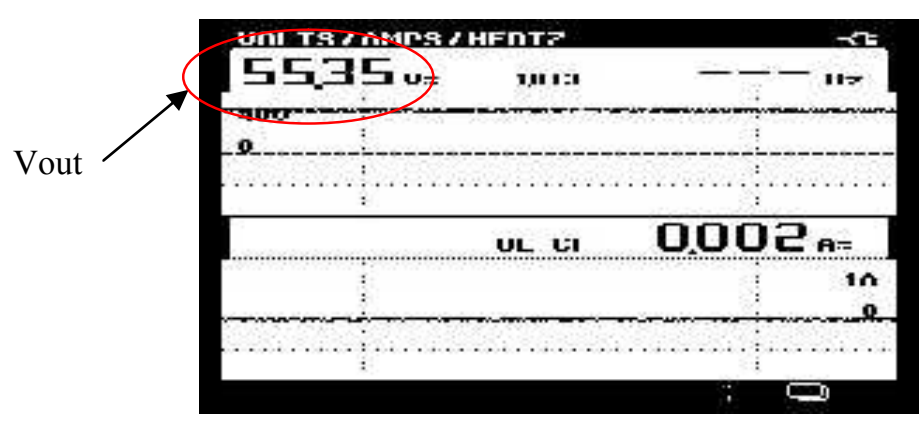

Gambar 8. Tegangan output rangkaian realisasi boost converter saat tegangan input $=12$ Volt

Pada Gambar 8, tegangan output boost converter seharusnya adalah sebesar 55 volt bukan 55,35 volt, penyimpangan ini terjadi akibat duty cycle yang memicu gate mosfet boost converter (lihatGambar 9) tidak tepat sama dengan $78,18 \%$. 
2. Hasil pengujian realisasi boost converter saat tegangan inputnya $=13$ volt

Saat tegangan input boost converter atau tegangan dari Power supply menunjukkan $=13$ volt , bentuk pulsa out rangkaian pemicu gate mosfet boost converter dan tegangan output yang dihasilkan dilihat pada Gambar 9 dan 10

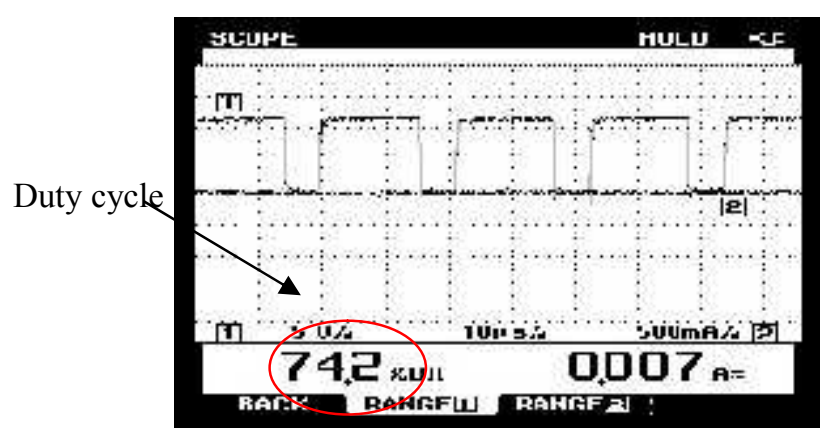

Gambar 9. Bentuk pulsa dan nilai duty cycle boost converter saat tegangan input $=13$ Volt

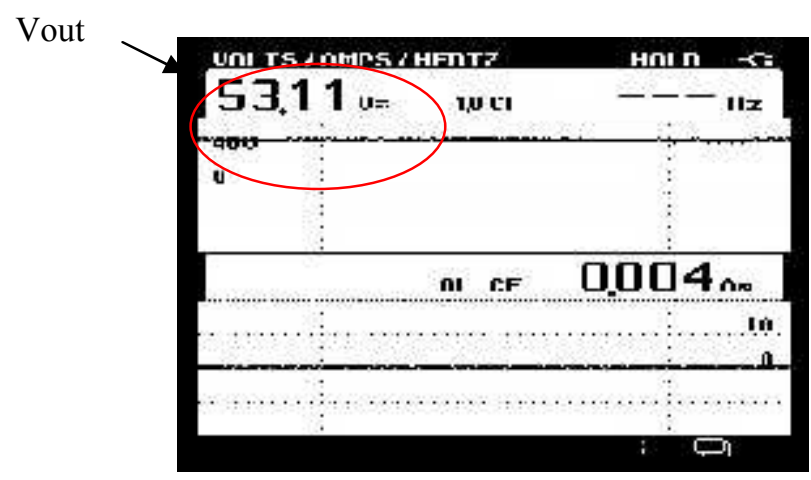

Gambar 10. Tegangan output rangkaian realisasi boost converter saat tegangan input $=13$ Volt

Dari gambar 10. saat tegangan dari power supply 13 volt didapatkan Vout 53,11 . Hasil pengukuran tegangan output rangkaian boost converter saat tegangan input dari power supply variable dc diatur pada tegangan $(14 ; 15 ; 16 ; 17 ; 18 ; 19 ; 20 ; 21 ; 22 ; 23 ; 24)$ dapat dilihat pada Tabel 5 
Tabel 5. Data hasil pengujian realisasi boost converter

\begin{tabular}{|c|c|c|}
\hline $\begin{array}{c}\text { Teg.Input } \\
\text { Realisasi (Volt) }\end{array}$ & $\begin{array}{c}\text { Duty cycle } \\
\text { Realisasi(D) }\end{array}$ & $\begin{array}{c}\text { Vout realisasi } \\
\text { Boost converter(Volt) }\end{array}$ \\
\hline 12 & 0,755 & 55,35 \\
13 & 0,742 & 53,11 \\
14 & 0,726 & 54,52 \\
15 & 0,709 & 54,75 \\
16 & 0,688 & 55,11 \\
17 & 0,672 & 55,68 \\
18 & 0,659 & 57,81 \\
19 & 0,634 & 59,51 \\
20 & 0,611 & 60,7 \\
21 & 0,606 & 59,84 \\
22 & 0,58 & 55,71 \\
23 & 0,566 & 55,42 \\
24 & 0,559 & 56,98 \\
\hline
\end{tabular}

ANALISIS hubungan duty cycle dan tegangan output boost converter berdasarkan hasil simulasi dan realisasi.

Didapatkan bahwa hasil pengukuran duty cycle yang diperoleh dari realisasi rangkaian ternyata tidak sama persis dengan duty cycle yang seharusnya (simulasi). Seperti grafik yang ditunjukkan pada Gambar 11. Oleh karena itu tegangan output yang dihasilkan dari realisasi rangkaian (Gambar 12 ) secara otomatis juga tidak sama persis seperti pada hasil simulasi

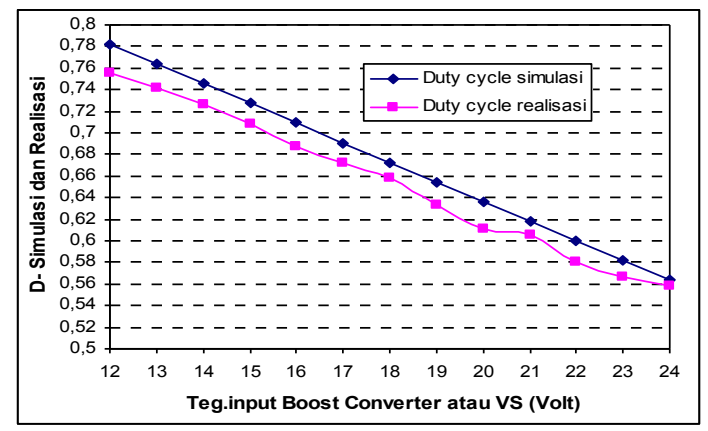

Gambar 11. Grafik hubungan tegangan input dan duty cycle rangkaian boost converter antara simulasi dan realisasi

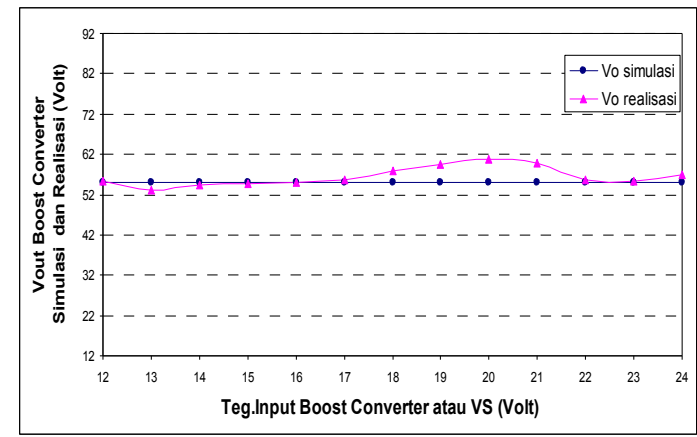

Gambar 12. Grafik hubungan tegangan input dan output rangkaian boost converter antara simulasi dan realisasi

Dari Gambar 12. dapat dilihat bahwa nilai tegangan output yang diperoleh dari rangkaian boost converter untuk menaikkan tegangan yang bervariasi 12 hingga 24 Volt menjadi 55 volt yang konstan belum tercapai dengan sempurna melainkan tegangan output yang terjadi berada pada range antara 53,11-60,7 Volt. Hal ini terjadi karena diakibatkan adanya pergeseran besar duty cycle dari rangkaian boost converter. 
Terjadinya pergeseran nilai duty cycle ini karena data output dari ADC yang dibaca oleh mikrokontroler ATMEGA8535 juga mengalami penyimpangan rata-rata turun 2 bit dari data output ADC yang seharusnya.

\section{Hasil pengujian rangkaian inverter satu fasa}

Pengujian inverter dilakukan dengan mengukur tegangan output inverter setelah semua bagian rangkaian dari perancangan sistem sudah terhubung. Pengukuran tegangan output inverter saat tegangan input boost converter 12 volt dan 24 volt ditampilkan pada Gambar 13 dan 14.

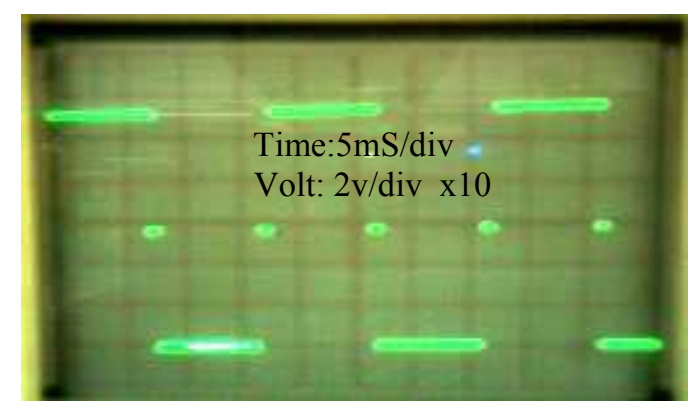

Gambar 13. Tegangan output inverter saat tegangan input boost converter 12 volt

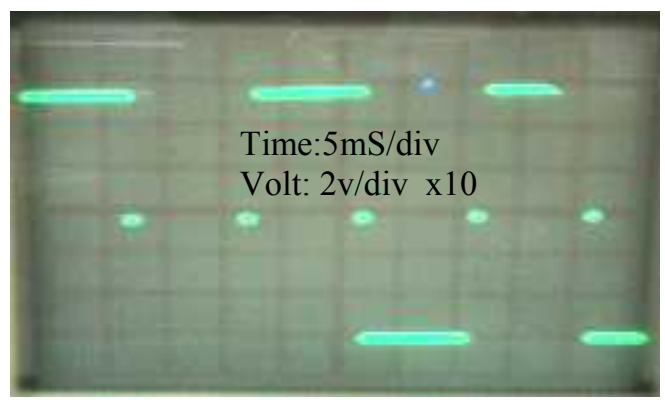

Gambar 14. Tegangan output inverter saat tegangan input boost converter 24 volt

Dari hasil pengukuran menggunakan oscilloscope dan voltmeter didapatkan tegangan output inverter pada Gambar 4.9 sebesar $53,2 \mathrm{Volt} / 50 \mathrm{~Hz}$ dan tegangan output inverter pada Gambar 14. sebesar
$54,96 \mathrm{Volt} / 50 \mathrm{~Hz}$. Harga tegangan output inverter dari kedua pengukuran tidak sama dengan $55 \mathrm{Volt} / 55 \mathrm{~Hz}$ sebab tegangan output dari boost converter (yang menjadi sumber tegangan input inverter) berbeda

\section{KESIMPULAN}

Dari pengujian dan pembahasan sebelumnya dapat ditarik kesimpulan sebagai berikut:

1. Rangkaian pengontrol tegangan output generator pada dasarnya dapat bekerja dengan baik.

2. Tegangan output inverter memang tidak tepat sama dengan sebesar 55 volt hal ini dikarenakan tegangan output dari boost converter sebagai sumber input bagi inverter tidak tepat sama dengan 55Volt melainkan berada pada range 53,11-60,7volt.

3. Penyimpangan hasil tegangan output inverter terbesar terjadi saat penyimpangan tegangan output boost converter yang terbesar, yaitu saat tegangan input boost converter sama dengan 20 volt, hal ini terjadi akibat penyimpangan data ADC yang dibaca oleh uC1 cukup besar.

4. Secara umum pada rangkaian dc chopper, perbedaan nilai duty cycle sangat mempengaruhi besar tegangan yang dihasilkan.

\section{DAFTAR PUSTAKA}

D.Hart, "Introduction to Power

Electronics, 1997.Prentice-Hall

Rasyid, Muhammad H., 1993 "Power

Electronic”, Prentice-Hall

Salam, Zainal,2002. "Power

Electronics and Drives"

Sugiyono,Agus,1988,Teknik

Penghilangan Harmonisa pada 
inverter satu fasa dengan

mikoprosesor sebagai pembangkit

sinyal kendali”, Tugas Akhir Jurusan

Teknik Elekto,ITB

Schuler, Charles A, “ Modern Industrial

Electronics”,1993. Singapore:

McGraw-Hill

William Kleitz, "Digital And

Microprocessor Fundamentals

Theory and Applications. 1990.

Prentice-Hall

Anonim, "Boost converter",

WWW.kettering.edu/ bguru/DC2DC/Boo

st.html

Anonim, "introduction of inverter", WWW.kettering.edu/ bguru/PEInvert ers.html

Anonim, "WWW.majorpower.com " 
ISSN: 2085-6989 